\title{
A New Record of Sea Urchin (Echinoidea: Echinoida) from Jejudo Island, Korea
}

\author{
Sook Shin* \\ Department of Life Science, Sahmyook University, Seoul 139-742, Korea
}

\begin{abstract}
Some sea urchins were collected from the subtidal rocky bottom of Munseom near Seogwipo, Jejudo Island by SCUBA diving from April to May, 2008 and identified on the basis of their morphological characteristics. Among them, Tripneustes gratilla (Linnaeus, 1758) of Family Toxopneustidae was newly recorded from Korea and redescribed on the specimen collected at a depth of $25 \mathrm{~m}$ between Munseom and Sekkiseom. The detailed morphological description was presented with the photographs. This species was characterized by the very naked median areas of ambulacral and interambulacral portions and this genus was the first record in Korea. Eighteen echinoids are so far recorded in Jejudo Island, Korea.
\end{abstract}

Key words: taxonomy, Echinoidea, Echinoida, Korea

\section{INTRODUCTION}

Echinoids play an important role in marine ecosystem as benthos and are mainly distributed in the neritic ocean and particularly abundant in the Indo-West Pacific and North Pacific Oceans. More than 900 species have been reported from all over the world up to the present time. Since the first report on Korean echinoids by Sladen (1879), 30 species have so far been reported in South Korea. Among them, 17 echinoid species such as Goniocidaris biserialis and Stereocidaris japonica of order Cidaroida, Prinocidaris baculosa and Coelopleurus undulatus polymorphus of order Arbacioida, Diadema setosum of order Diadematoida, Asthenosoma ijimai of order Echinothurioida, Mespilia globalus, Microscyphus olivaceus, Pseudocentrotus depressus, Toxopneustes pileolus, Hemicentrotus pulcherrimus and Anthocidaris crassispina of order Echinoida in subcalss Regularia, Clypeaster japonicus, C. virescens and Astriclypeus manni of order Clypeastroida, Pseudomaretia alta and Brissus agassizi of order Spatangoida in subclass Irregularia, have been reported in the Jejudo Island. Eleven species of these 17 species were found only in the area of Jejudo Island (Shin, 2000; Shin et al., 2006).

Some sea urchins were collected from the subtidal rocky bottom at depth $25 \mathrm{~m}$ between Munseom and Sekkiseom of Seogwipo, Jejudo Island by SCUBA diving from April to May, 2008. Samples were preserved in $75 \%$ methyl alcohol and identified on the basis of their morphological character-

*To whom correspondence should be addressed

Tel: 82-2-3399-1717, Fax: 82-2-3399-1729

E-mail: shins@syu.ac.kr istics. Among them, Tripneustes gratilla (Linnaeus, 1758) of the Family Toxopneustidae of the order Echinoida which is the largest order of the subclass Irregularia in the class Echinoidea was newly recorded from Korea. The taxonomic characters of this species were photographed using stereomicroscope and lightmicroscope. This genus Tripneustes was the first record in Korea. And 18 echinoids were recorded to be distributed in Jejudo Island, Korea. Jejudo Island is the most abundant area which exhibited the highest diversity of echinoids in Korea (Shin and Rho, 1996). The systematic scheme on the identified echinoids was adopted from that of Shigei (1986).

\section{SYSTEMATIC ACCOUNTS}

Phylum Echinodermata Klein, 1734

Class Echinoidea Leske, 1778

Subclass Regularia Latreille, 1825

Order Echinoida Claus, 1876

Family Toxopneustidae Troschel, 1872

Genus ${ }^{1 *}$ Tripneustes L. Agassiz, 1841

Test hemispherical to subglobular. Ambulacra with trigeminate plates, with a primary tubercle on every three to four plates; pore-pairs form nearly three vertical series. Median area in both ambulacra and interambulacra conspicuously naked. Spines short, sharply pointed.

Type-species: Echinus ventricosus Lamark, 1816

\footnotetext{
2*Tripneustes gratilla (Linnaeus, 1758) (Fig. 1A-Q) Echinus gratilla Linnaeus, 1758, p. 664.
}

${ }^{1 *}$ 흰수염성 게속 (신칭), ${ }^{2}$ *흰수염성 게 (신칭) 

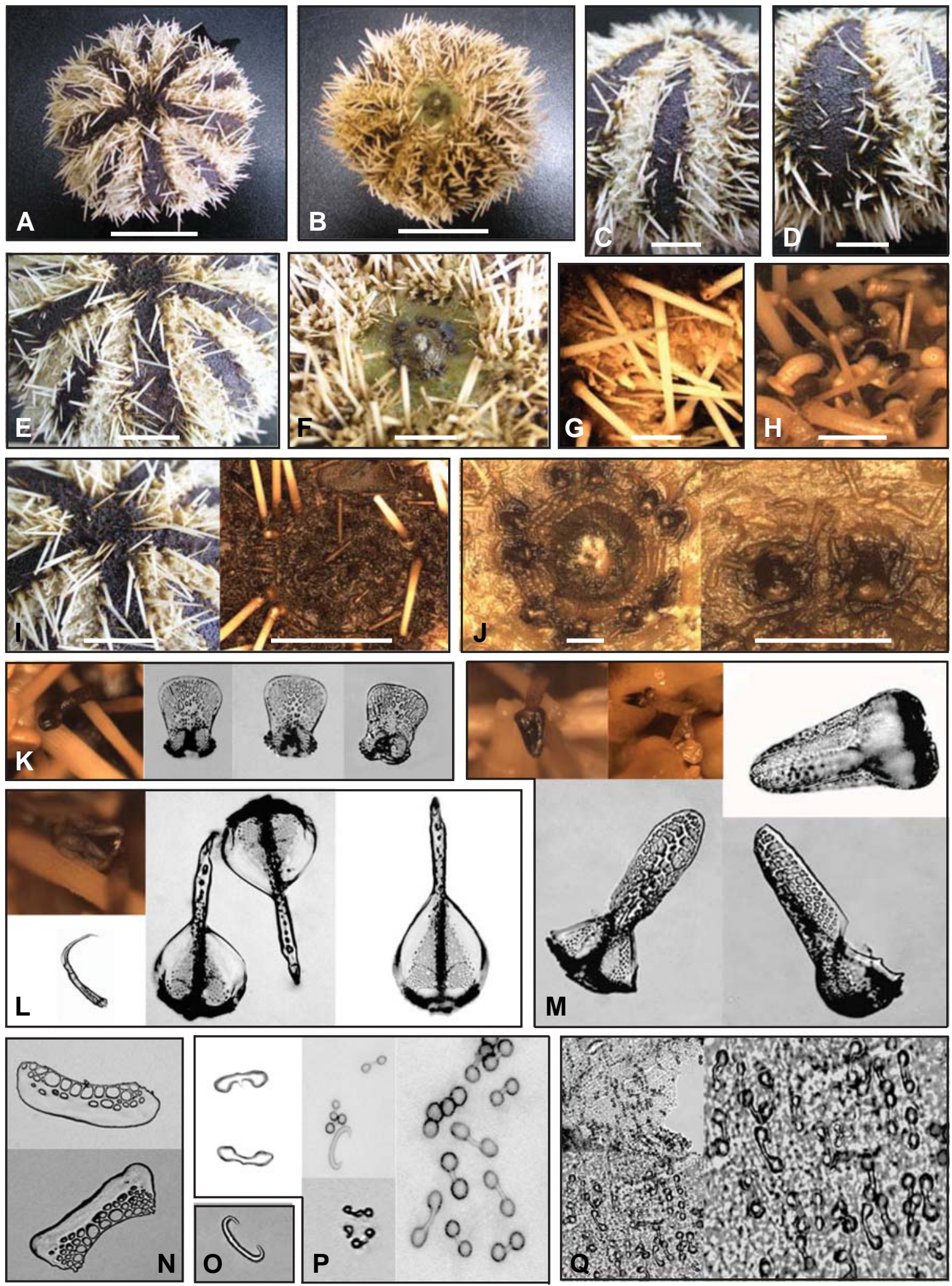

Fig. 1. Tripneustes gratilla. $A$, aboral side; $B$, oral side; $C$, ambulacra of aboral side; $D$, interambulacra of aboral side; $E$, interambulacra and ambulacra of aboral side; $F$, J, peristome; G, spines; $H$, podia; $I$, apical system; $K$, triphyllous pedicellariae; $L$, globiferous pedicellariae; $M$, tridentate pedicellariae; $N$, $O$, spicules of tube-feet; $P, Q$, curved dumbbell-shaped spicules embedded in tube-feet. Scale bars $=3 \mathrm{~cm}(A, B), 1 \mathrm{~cm}(C-F, I), 5 \mathrm{~mm}(\mathrm{G}), 3 \mathrm{~mm}(\mathrm{H}), 2 \mathrm{~mm}$ (J). 
Hipponoё variegata Yoshiwara, 1900, p. 386; Tokunaga, 1906, pl. 13; A. Agassiz and H.L. Clark, 1907, p. 246.

Tripneustes variegatus Mortensen, 1903, p. 113.

Tripneustes gratilla Mortensen, 1903, p. 137; Djakonov, 1930, p. 234; Ohshima, 1947, p. 587; Utinomi, 1962, p. 115; Chang et al., 1964, p. 88; Nishiyama, 1968, p. 349; A.M. Clark and Rowe, 1971, p. 142; Liao, 1978, p. 115; Shigei, 1981, p. 200; 1986, p. 87; Saba et al., 1982, p. 35.

Material examined. One specimen, 18 April 2008, S.H. Park, on rocky sediment, at depth $25 \mathrm{~m}$ between Munseom and Sekkiseom of Seogwipo, Jejudo Island.

Description. Horizontal diameter $=67 \mathrm{~mm}$, Vertical diameter $=45 \mathrm{~mm}$, Longest spine $=25 \mathrm{~mm}$.

Test large, somewhat semi-globular and somewhat sunken towards the peristome. Median area in both ambulacra and interambulacra completely naked and purplish black in colour with a radiating appearance.

Ambulacra: Ambulacra with trigeminate plates, with a primary tubercle on every three to four plates. Ambulacral width more than three fourth that of interambulacra at ambital region. Pore-zones scarcely sunken and broad, a little more than half width of an interporiferous zone. Pore-pairs arranged in nearly three vertical series, of which inner and outer series very regular but median series somewhat irregular. Primary tubercles reach about same size as primary interambulacral plates and set on every third or fourth plate on aboral side. Secondary tubercles rather irregularly arranged, not forming regular series, except in ambital region and in pore-zones where they form one or two distinct, regular series. Miliary tubercles rather few in number. Median areas broad and naked.

Interambulacra: Primary tubercle series alone reach to apical system. Secondary tubercles reach about same size as primary ones in ambitus and form a conspicuous horizontal series on each plate and also some more or less regular vertical series which extend to midway. Miliary tubercles rather few in number. Median areas remarkably broad and naked.

Apical system: Anal opening subcentral. Apical plates provided with many miliary tubercles and a few larger tubercles mainly along their inner edges.

Peristome small, about one fourth diameter of test. Buccal plates widely apart each other and carry a considerable number of pedicellariae which not crowded. Gill-slits prominent, deep and long.

Spines short and simple, tapering gently towards point. Ones on aboral side much pointed than those on oral side.

Pedicellariae very numerous on median areas of both ambulacra and interambulacra on aboral side, Tridentate pedicellariae have narrow valves meeting only distally. Smaller ones with relatively broader valves. Triphyllous pedicellariae of usual types.

Spicules of tube feet c-shaped and very numerous peculiar forms of small curved dumbbell-shaped.

Colour: Median areas of both ambulacra and interambulacra purplish black. Denuded test more or less purplish, with a radiating appearance showing purplish median areas and whitish outer zones. Spines generally white; Pedicellariae usually black except ones around peristome region which shows much lighter brown in colour. Tube feet uniformly white but sometimes with a black broad band at nearly middle part.

Remarks. Only one specimen was collected but immediately identified due to the very conspicuous morphological characteristics. This species has somewhat semi-globular test, and median area in both ambulacra and interambulacra remarkably naked and purplish black in colour with a radiating appearance. In addition, its tube feet have microscopic c-shaped spicules and very numerous peculiar curved dumbbell-shaped spicules.

Distribution. Korea (Jejudo Island); Japan (Sagami Bay, Boso Peninsula); Indo-West Pacific (southeastern Africa-Hawaii, Australia).

\section{ACKNOWLEDGEMENTS}

This work was partially supported by Sahmyook University Research Fund in 2008.

\section{REFERENCES}

Agassiz, A. and H.L. Clark, 1907. Preliminary reports on the echini collected in 1902, among the Hawaiian Island, by the U.S. Fish Commission Steamer "Albatross", in charge of Commander Chaucey Thomas, U.S.N. Commanding. Bull. Mus. Comp. Zool., 50: 231-259.

Chang, F.Y., Y. Liao, H. Go and H. Tei, 1964. Echinoids. In Illustrated Encyclopedia of Chinese Animals (Echinoderms). Kexue (Science) Pub. Peking, pp. 74-101 (in Chinese).

Clark, A.M. and F.W.E. Rowe, 1971. Monograph of shallowwater Indo-West-Pacific Echinoderms. Brit. Mus. Publ. (Nat. Hist.), 690: 1-238.

Djakonv, A.M., 1930. Echiniden, Ophiuriden und Asteriden, gesammelt von Prof. P.J. Schmidt bei den Riu-Kiu Inseln in Jahre 1926-1927. Zool. Jahrb., Abt. Syst., Oek. Geogr., 59: 233-252, pls. 12-13.

Linnaeus, C., 1758. Systema Naturae per Regna tria Naturae secundum Classes, Ordines, Genera, Species, cum Characteribus, Differentis, Synonymis, Locis, Editio decima reformata; Tomus I. Laurenti, Salvii, Holmiae, 8: 1-824 (cited from Nisiyama, S. 1966).

Liao, Y., 1978. The Echinoderms of the Xisha Islands, Guan- 
dong Province. China. III, Echinoidea. Stud. Mar. Sin., 12: 107-127, text-figs. 1-13, pls. 1-5.

Ohshima, H., 1947. Echinoidea. In IIIustrated Encyclopedia of the Fauna of Japan (revised ed.), pp. 576-596, Hokuryukan, Tokyo (in Japanese).

Mortensen, Th., 1903. The Danish Ingolf-Expedition. 4 (Echinoidea, Part 1): 1-198, 12 text-figs., pls, 21-25.

Nisiayma, S., 1968. The Echinoid fauna from Japan and adjacent Regions Part II. Paleon. Soc. Japan, (13): 1-491, pls. 19-30.

Saba, M., Y. Tomida and T. Kimoto, 1982. Echinoderm fauna of Ise Bay, and the northern and the middle parts of Kumanonada. Bull. Mie Pref. Mus. Nat. Sci., 4: 1-82, pls. 1-34.

Shigei, M., 1981. A study on the echinods fauna of the East China Sea and the coastal waters of southern Korea, Kyushu, Ryukyu and Taiwan. Publs. Seto Mar. Biol. Lab., 26: 192-241.

Shigei, M., 1986. The sea urchins of Sagami Bay, Biol. Lab. Imp. Hous., Marugen Co. Ltd., Tokyo, pp. 1-204. pls. 1126.
Shin, S. and B.J. Rho, 1996. Illustrated Encyclopedia of Fauna \& Flora of Korea. Vol. 36 Echinodermata. Min. Educ., pp. $1-780$.

Shin, S., 2000. New record of two echinoids (Echinodermata, Echinoidea) in Korea. Korean J. Syst. Zool., 16(2): 219-226.

Shin, S., J. Pyo and S.H. Kim, 2006. A new record of sea urchin (Echinoidea: Echinothuroida) in Korea. Korean J. Syst. Zool., 22(1): 105-108.

Sladen, W.P., 1879. On the Asteroidea and Echinoidea of the Korea Seas. J. Linn. Soc. London, 14: 424-445.

Utinomi, H., 1962. Recent evidence for northward extension of the range of some tropical echinoderms in Japanese waters. Zool. Mag., 71: 102-108 (in Japanese).

Tokunaga, S., 1906. Japanese Echini (Plates). Zool. Mag., 18: pls. 8-13.

Yoshiwara, S., 1900. Japanese Echinoids. Zool. Mag., 12: 379405.

Received October 29, 2008 Accepted November 17, 2008 